\title{
A Regional Analysis of Literacy and Educational Levels of Scheduled Caste in Uttar Pradesh
}

\author{
Farhana Khatoon
}

\begin{abstract}
Literacy is a sensitive indicator of cultural advancement of an area. Literacy helps a social group to acquire a higher social status through the process of social mobility. The abysmally low rates of growth in literacy have been the result of faulty educational policy of British Government in India. The British policy of providing education to the elite resulted in neglect of mass education. The socio-economic base of education in colonial India was extremely narrow and the door of education was closed for the economically and socially deprived sections of the society. There is a wide disparity in educational opportunities between scheduled and non-scheduled population of India. The main objective of the paper is to highlight the literacy status of scheduled castes in Uttar Pradesh and present a district wise analysis. In this paper an attempt has been made to present the educational status of scheduled caste since 1911. The first two section of the paper is devoted to the analysis of scheduled caste education during British period. The subsequent sections dealt with impact of post independence efforts. In the last section an attempt has also been made to assess the sex disparity in literacy within scheduled caste and disparity between scheduled and non-scheduled population. We find that the percentage of literates within scheduled caste population is particularly small in the districts in which their population is high. Another interesting feature is that all those districts where literacy among general population is high, scheduled caste literacy are also high.
\end{abstract}

\section{Introduction:}

Literacy is a sensitive indicator of cultural advancement of an area. Literacy helps a social group to acquire a higher social status through the process of social mobility. The United Nations Educational Scientific and Cultural Organization (UNESCO) has defined literacy as the, "ability to identify, understand, interpret, create, communicate and compute, using printed and written materials associated with varying context. Literacy involves a process of learning to enable an individual to achieve his or her goals to develop his or her knowledge and potential and to participate fully in the wider society"1.

The abysmally slow rates of growth in literacy have been the result of the faulty educational policy of British Government in India. The British policy of providing education to the elite resulted in neglect of mass education. The socio-economic base of education in colonial India was extremely narrow and the door of education was closed for the economically and socially deprived sections of the society. There is a wide disparity in educational opportunities between scheduled and non-scheduled population of India. The situation of Uttar Pradesh is not different from the country, Infact in terms of literacy it is one of the most backward state in the country.

The main objective of the paper is to highlight the literacy status of scheduled castes in Uttar Pradesh and present a district wise analysis. In this paper an attempt has been made to present the educational status of scheduled caste since 1911. The first two section of the paper is devoted for the analysis of scheduled caste education during British period. The subsequent sections dealt with impact of post independence efforts. In the last section an attempt has also been made to assess the sex disparity in literacy within scheduled caste and disparity between scheduled and non-scheduled population.

\section{Literacy/ Educational Status during British Period}

\section{Scheduled Castes:}

In the beginning of the $18^{\text {th }}$ century several educational institutions were established in the United Provinces by missionaries. The modern system of education took its root in the state when Jonathan Duncan in 1791, established a Sanskrit pathshala at Varanasi. At the close of 1850 three types of elementary schools existed in this Province, they were the Tahsili, Halkabandi and Indigenous schools. History of educational development shows that the condition of the backward classes in this regard was miserable. Their sad state of affair was the result of neglected Government policy and social stigma. The primary schools for the students belonging to the backward or the depressed classes were first started in 1910. In 1919-20, supervisors had been

\footnotetext{
${ }^{1}$ Dana Dunn (1993), "Gender Inequality in Education and Employment in the Scheduled Castes and Tribes of India”, Population Research and Policy Review, Vol. 12.
} 
appointed for these schools on experimental basis in the district of Meerut, Varanasi and Jaunpur. In another effort a scheme for the opening of special schools for depressed classes was chalked out in 1921 and financial assistance was provided to the district boards. Because of all these efforts there was marked increase in the number of primary schools specially opened for the depressed classes and also in the number of backward class students attending all schools. The following statistics show this ${ }^{2}$.

Table 1: Number of Depressed Class Students in Schools, 1931-1933

\begin{tabular}{|c|c|c|c|c|}
\hline Year & $\begin{array}{l}\text { Number of } \\
\text { Depressed Class } \\
\text { Schools }\end{array}$ & $\begin{array}{l}\text { Number of } \\
\text { Depressed } \\
\text { Class Students }\end{array}$ & $\begin{array}{l}\text { Others } \\
\text { Students }\end{array}$ & $\begin{array}{l}\text { Total Enrolment of } \\
\text { Depressed Class } \\
\text { students }\end{array}$ \\
\hline $\mathbf{1 9 3 1} \mathbf{- 3 2}$ & 757 & 17,888 & 8,186 & 113,228 \\
\hline $\mathbf{1 9 3 2}-\mathbf{3 3}$ & 757 & 18,443 & 9,267 & 115,992 \\
\hline
\end{tabular}

Source: The Figures have been taken from the 'General Report on Public Instruction in the United Provinces of Agra and Oudh, 1933, Allahabad.

Scheduled castes were the victims of social ostracism due to the practice of untouchability. Because of this social evil their educational development suffered a lot.

Traditionally Indian society is characterized by social exclusion and glaring inequalities are structured in it on this basis. Hierarchical caste relations are the bedrock of the Hindu society. The modes of living, working and ideology that make up this stratification have developed an in-built mechanism for perpetuating the system $^{3}$. Though this has been the practice as far back as the history of Indian society can be traced, the caste based inequality and deprivation reached its extreme form under British colonialism. British educational policy of "Downward Filtration Theory" also exercised its impact on equality of educational opportunities. Thus the traditional caste system in which education was the prerogative of the upper castes, and the British policy of providing education to the elite reinforced each other to produce a social segregation in the educational arena of the society ${ }^{4}$.

The condition of Backward Castes in Uttar Pradesh was more depressing. Within this caste there was a wide variation in terms of percentages of literates. The practice of untochability and pathetic economic conditions of the Backward Castes were responsible for this sad state of affairs. Among the Backward Castes, depressingly low literacy rates were observed among all the castes. Chamar which constituted the greater share of total population that is 16.29 percent had the only 0.11 percent of the literate population. The mass illiteracy of this section was attributable to a long history of their association with occupations (agricultural labour, sanitary services) for which literacy had little functional value. Moreover appalling poverty was another powerful deterrent to the propagation of education where the parents did not send their children to schools but instead sent them for work with a view to augmenting their family income. Relatively high literacy was recorded among Koeri (Kori) i.e. 1.08 percent. Female literacy among all the castes of this group was nearly zero.

Table 2: Caste-Wise Population and Literacy In Uttar Pradesh, 1911

\begin{tabular}{|l|r|r|r|r|r|r|}
\hline Castes & \multicolumn{9}{|c|}{ Population } & \multicolumn{3}{l|}{ Percentage of Literates } \\
\hline Backward Castes & 6068382 & 3099321 & 2969061 & 0.11 & 0.20 & 0.02 \\
\hline Chamar & 716100 & 369650 & 346450 & 0.16 & 0.27 & 0.04 \\
\hline Dhobi & 1303100 & 665847 & 637253 & 0.14 & 0.26 & 0.02 \\
\hline Pasi & 92122 & 49016 & 43106 & 0.48 & 0.81 & 0.11 \\
\hline Khatik & 124739 & 66689 & 58050 & 0.19 & 0.33 & 0.01 \\
\hline Dhanuk & 306494 & 158186 & 148308 & 0.62 & 1.16 & 0.05 \\
\hline Dom & 417609 & 212783 & 204826 & 1.08 & 2.09 & 0.04 \\
\hline Koeri (Kori) & 69557 & 33458 & 36099 & 0.24 & 0.48 & 0.03 \\
\hline Dusadh & &
\end{tabular}

Source: Census of India 1911, United Provinces of Agra and Oudh, Vol. XV

Notes: The Category of Backward Castes is based on 1931 Census Classification of Backward Castes

${ }^{2}$ General Report on Public Instruction in the United Provinces of Agra and Oudh, 1933, Allahabad

${ }^{3}$ B.B. Mohanty (2002), "Development of Scheduled Castes: An Overview", IASSI Quarterly, Vol. 20, No. 3, pp. 108-117.

${ }^{4}$ Jacob Aikara (1996), "Inequality of Educational Opportunities: The Case of Scheduled Castes in India", Journal of Educational Planning and Administration, Vol. X, No. 1, pp. 1-14. 


\section{Literacy/ Education after Independence:}

After Independence number of provisions has been made for the development of scheduled caste. Article 46 of the Indian constitution lays down a directive principle of the state policy which provides that "the state shall promote with special care the educational and economic interests of the people and, in particular, of the scheduled castes and scheduled tribes and shall protect them from social injustice and all forms of exploitation". The educational development of a region is an index of social development. In a region where all sections of society are literate, overall educational achievement is also high. So here in this section an attempt has been made to review the progress of literacy among scheduled castes of Uttar Pradesh. In this state caste prejudices are most prevalent and it is very much reflected in the educational achievement of the weaker sections of the state. After independence several steps have been taken to improve the educational status of backward classes. To analyze the progress of literacy two time period 1961 and 2001 has been taken into consideration.

Table 3: Literacy Rates among Scheduled Caste and Non-Scheduled Population In Uttar Pradesh: 1961 - 2001

\begin{tabular}{|c|c|c|c|c|}
\hline \multicolumn{3}{|c|}{ Scheduled Caste population } & \multicolumn{2}{|c|}{ Non-Scheduled Population } \\
\hline & 1961 & 2001 & 1961 & 2001 \\
\hline Total Population & 6.97 & 36.75 & 20.11 & 47.92 \\
\hline Male & 12.49 & 48.12 & 30.50 & 57.92 \\
\hline Female & 1.11 & 24.11 & 8.53 & 36.79 \\
\hline Rural Population & 6.10 & 35.16 & 16.39 & 44.16 \\
\hline Rural male & 11.27 & 46.81 & 26.65 & 55.45 \\
\hline Rural female & 0.66 & 22.27 & 5.13 & 31.67 \\
\hline Urban Population & 18.70 & 48.06 & 42.12 & 60.47 \\
\hline Urban male & 28.05 & 57.28 & 52.08 & 66.03 \\
\hline Urban female & 7.57 & 37.45 & 29.88 & 54.14 \\
\hline
\end{tabular}

The levels of educational attainment among scheduled caste population are so low that a predominantly large proportion of population has continued to remain illiterate and outside the ambit of education. It is no doubt that educational status of scheduled castes population has improved during last sixty years, yet the gain is not satisfactory. More disaggregated level analysis shows the persistence of intra and inter group disparities in the levels of literacy. Expressed in terms of the gains by different strata of the scheduled caste population it has been observed that maximum gain has been registered for the urban males and minimum has been in the case of rural females.

\section{Spatial Pattern of Literacy, 1961 - 2001:}

One of the characteristic of educational achievement of Uttar Pradesh is that there exist large scale disparities in literacy between different regions, social groups and religious groups. The low levels of educational development among the various strata of society are both the cause and the effect of socio-economic disparities between them. The analysis about the progress of literacy in the total population shows that over all literacy rates of the state was 17.34 percent in 1961 which rose to 45.56 percent in 2001.The district-wise literacy scenario reveals an interesting pattern. If one analyses the spatial distribution pattern of literacy for 46 districts (based on 1961 census), one finds that there is a polarization of literacy rates in the eastern and western districts.

Fig 1
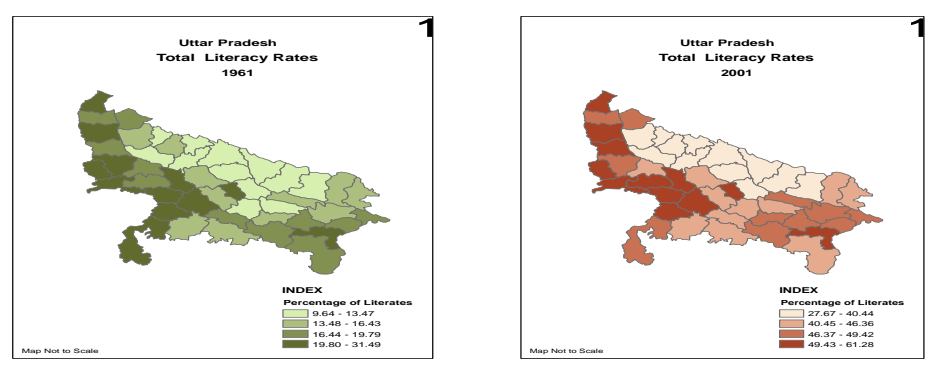

\footnotetext{
${ }^{5}$ N. Mishra (2001), "Scheduled Castes Education: Issues and Aspects”, Kalpaz Publications, Delhi.
} 


\section{Literacy among Scheduled Castes:}

In 1961 majority of the districts shows literacy rates between 2 percent to 10 percent. Agra, Farrukhabad, Meerut, Mainpuri, Jalaun, Etawah and Kanpur had literacy rates between 10 - 15 percent. The eastern districts are more deprived than the western districts. In 2001 majority of the districts had literacy rates between 21-35 percent. Some of the districts which show literacy rates between 35-40 percent are Fatehpur, Faizabad, Gorakhpur, Unnao, Pilibhit, Bareilly, Etah, Varanasi, Banda, Hamirpur, Jaunpur, Azamgarh, Ballia, Ghazipur, Farrukhabad and Aligarh. While the districts which show literacy rates 45 -50 percent are Saharanpur, Meerut, Mainpuri, Etawah, Kanpur and Jalaun. This clearly indicates that only those districts which were better off in terms of literacy in 1961, shows significantly high literacy rates in 2001 also.

\section{Fig 2}
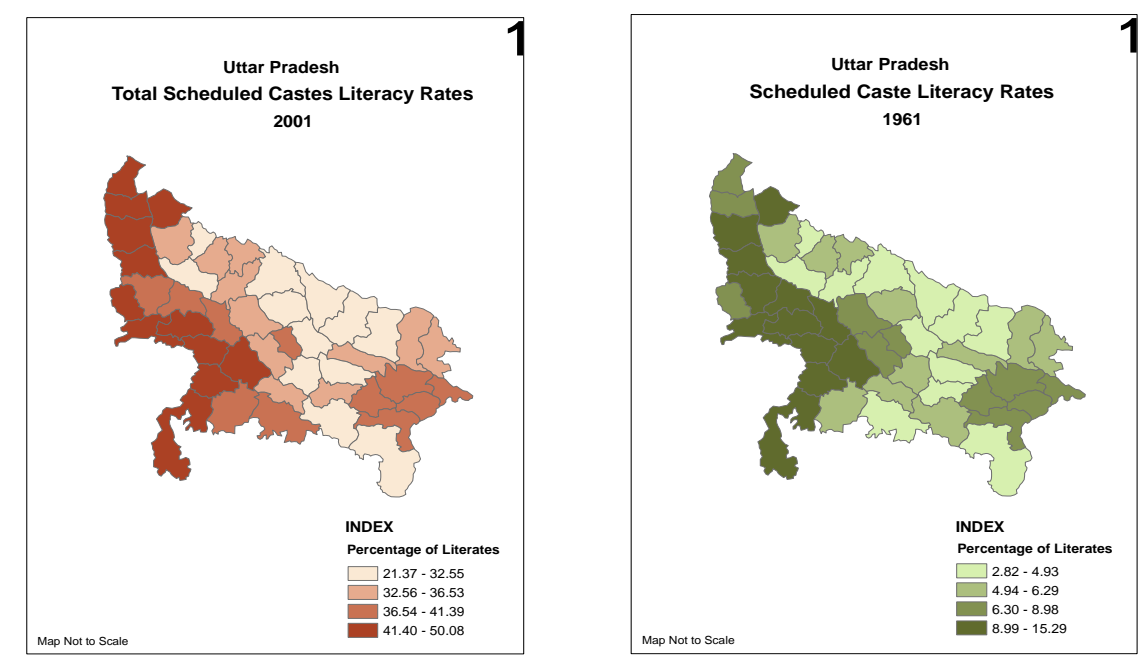

\section{Educational Attainment among Scheduled Caste Population Primary Level of Education by Districts:}

Since scheduled castes are viewed as the most deprived, disadvantaged and suffering sections of the society, it is necessary to assess progress made by them in different levels of education. The primary level of education among scheduled castes increased from 1.54 percent in 1961 to 22.22 percent in 2001 . Correspondingly the attainment of the primary level of education among the female population in 1961 and 2001 was 0.18 percent and 17.18 percent respectively. In 1961, Etawah (3.23 percent) had the highest percentages of scheduled castes literate at the primary level followed by Mainpuri (3.00 percent), Kanpur (2.72 percent), Meerut (2.65 percent), Farrukhabad (2.44 percent), Jalaun (2.24 percent), Etah (2.23 percent) and Lucknow (2.10 percent). One can see that these percentages were very low. The lowest shares of literate at the primary level were recorded in the entire eastern part of the state. The situation of female educational attainment was pitiable in this respect. The over all educational attainment of the scheduled castes at the primary level increased in 2001, but when we compare this level with that of the general population, they still lagged behind. Saharanpur (30.05 percent) shows high literacy among scheduled castes at the primary stage, while the lowest was in Bahraich (13.96 percent). Banda district has made significant progress over the period in scheduled caste primary level of literacy.

\section{Attainment of Matriculation \& above Level of Education among Scheduled Castes by Districts:}

As we move higher in the pyramid of educational level, the share of Scheduled Castes has declined. In 1961 , just 0.29 percent of the total scheduled castes educated at the matriculation and above level. The share of females in this respect was abysmally low. While in 2001, the condition improved slightly in comparison to 1961 and the scheduled caste share rose to 12.84 percent and that of scheduled caste females to 5.59 percent. But when we compare these shares with the general population, the scheduled castes were most backward. Among the districts, Meerut (21.83 percent) shows a high percentage of scheduled castes educated at the matriculation and above level closely followed by Etawah (21.22 percent) Jalaun (20.56 percent) and Kanpur (19.56 percent). On the other end of the scale were the districts of Bahraich (5.62 percent), Gonda (5.89 percent), 
Kheri (7.77 percent) and Budaun (7.82 percent). The condition of female higher education was also poor in these districts.

Table 4: Attainment of Primary Level of Education among Scheduled Caste Population in Uttar Pradesh, 1961-2001

\begin{tabular}{|c|c|c|c|c|c|c|}
\hline \multirow{3}{*}{ Districts } & \multicolumn{6}{|c|}{$\begin{array}{c}\text { Primary Level } \\
\text { (percentages to the total SC population) }\end{array}$} \\
\hline & \multicolumn{3}{|c|}{1961} & \multicolumn{3}{|c|}{2001} \\
\hline & Total & Male & Female & Total & Male & Female \\
\hline Uttar Pradesh & 1.54 & 2.83 & 0.18 & 22.22 & 26.75 & 17.18 \\
\hline Saharanpur & 1.56 & 2.74 & 0.20 & 30.05 & 33.62 & 25.90 \\
\hline Muzaffarnagar & 1.66 & 3.00 & 0.12 & 27.61 & 31.76 & 22.78 \\
\hline Bijnor & 2.27 & 3.90 & 0.50 & 25.96 & 29.56 & 21.88 \\
\hline Moradabad & 1.80 & 3.18 & 0.21 & 20.77 & 25.31 & 15.52 \\
\hline Rampur & 0.96 & 1.73 & 0.08 & 18.34 & 22.75 & 13.27 \\
\hline Meerut & 2.65 & 4.78 & 0.22 & 27.24 & 30.34 & 23.63 \\
\hline Bulandshahr & 1.59 & 3.03 & 0.06 & 25.43 & 30.57 & 19.48 \\
\hline Aligarh & 1.57 & 2.81 & 0.17 & 24.17 & 28.56 & 19.06 \\
\hline Mathura & 1.64 & 3.00 & 0.11 & 25.61 & 30.53 & 19.84 \\
\hline Agra & 1.72 & 2.98 & 0.22 & 24.05 & 28.22 & 19.11 \\
\hline Mainpuri & 3.00 & 4.97 & 0.67 & 26.74 & 29.33 & 23.70 \\
\hline Etah & 2.23 & 3.96 & 0.24 & 22.05 & 26.10 & 17.24 \\
\hline Budaun & 0.83 & 1.45 & 0.07 & 19.22 & 23.32 & 14.35 \\
\hline Bareilly & 1.30 & 1.99 & 0.45 & 22.81 & 26.16 & 18.91 \\
\hline Pilibhit & 1.61 & 2.87 & 0.14 & 24.01 & 28.33 & 19.05 \\
\hline Shahjahanpur & 1.27 & 2.28 & 0.07 & 22.55 & 26.09 & 18.32 \\
\hline Kheri & 1.36 & 2.48 & 0.11 & 20.94 & 25.60 & 15.63 \\
\hline Sitapur & 1.61 & 2.97 & 0.08 & 20.88 & 25.68 & 15.32 \\
\hline Hardoi & 1.97 & 3.58 & 0.14 & 22.39 & 27.21 & 16.59 \\
\hline Unnao & 1.40 & 2.53 & 0.17 & 23.36 & 28.07 & 18.20 \\
\hline Lucknow & 2.10 & 3.59 & 0.41 & 23.41 & 26.68 & 19.76 \\
\hline Rae Bareli & 0.97 & 1.85 & 0.08 & 20.47 & 26.13 & 14.63 \\
\hline Farrukhabad & 2.44 & 4.10 & 0.35 & 24.10 & 27.19 & 20.44 \\
\hline Etawah & 3.23 & 5.64 & 0.45 & 27.18 & 28.82 & 25.22 \\
\hline Kanpur & 2.72 & 3.97 & 1.23 & 24.74 & 26.75 & 22.38 \\
\hline Jalaun & 2.24 & 4.16 & 0.13 & 25.39 & 28.13 & 22.10 \\
\hline Jhansi & 1.97 & 3.64 & 0.16 & 24.51 & 29.49 & 18.84 \\
\hline Hamirpur & 0.87 & 1.67 & 0.06 & 23.88 & 29.09 & 17.76 \\
\hline Banda & 0.67 & 1.27 & 0.04 & 24.69 & 30.21 & 18.34 \\
\hline Fatehpur & 1.37 & 2.61 & 0.07 & 22.32 & 26.94 & 17.18 \\
\hline Pratabgarh & 1.38 & 2.83 & 0.10 & 21.86 & 27.48 & 16.43 \\
\hline Allahabad & 1.38 & 2.49 & 0.25 & 18.57 & 23.67 & 12.91 \\
\hline Barabanki & 0.86 & 1.63 & 0.03 & 18.34 & 22.80 & 13.33 \\
\hline Faizabad & 1.35 & 2.73 & 0.03 & 21.80 & 26.47 & 17.01 \\
\hline Sultanpur & 0.59 & 1.19 & 0.02 & 20.99 & 26.59 & 15.24 \\
\hline Bahraich & 0.81 & 1.55 & 0.02 & 13.96 & 18.97 & 8.07 \\
\hline Gonda & 0.82 & 1.53 & 0.10 & 14.78 & 20.76 & 8.05 \\
\hline Basti & 0.82 & 1.59 & 0.03 & 19.37 & 24.94 & 13.49 \\
\hline Gorakhpur & 1.49 & 2.93 & 0.14 & 21.07 & 26.49 & 15.43 \\
\hline Deoria & 1.47 & 2.95 & 0.07 & 19.51 & 24.90 & 14.02 \\
\hline Azamgarh & 1.10 & 2.22 & 0.08 & 22.26 & 26.78 & 17.85 \\
\hline Ballia & 2.00 & 4.01 & 0.10 & 19.33 & 22.87 & 15.59 \\
\hline Jaunpur & 1.43 & 2.98 & 0.06 & 22.39 & 27.92 & 16.91 \\
\hline Ghazipur & 1.32 & 2.63 & 0.09 & 21.36 & 25.44 & 17.14 \\
\hline Varanasi & 1.42 & 2.65 & 0.20 & 21.70 & 26.72 & 16.16 \\
\hline Mirzapur & 0.78 & 1.51 & 0.04 & 18.32 & 24.65 & 11.38 \\
\hline
\end{tabular}

Source: Census of India, Uttar Pradesh, Social and Cultural Tables, 1961 and 2001 
Table 5: Attainment of Matriculation and above Level of Education Among Scheduled Caste Population in Uttar Pradesh, 1961-2001

\begin{tabular}{|c|c|c|c|c|c|c|}
\hline \multirow{3}{*}{ Districts } & \multicolumn{6}{|c|}{$\begin{array}{c}\text { Matriculation \& above Level } \\
\text { (percentages to the total Sc population) }\end{array}$} \\
\hline & & 1961 & & & 2001 & \\
\hline & Total & Male & Female & Total & Male & Female \\
\hline Uttar Pradesh & 0.29 & 0.53 & $\mathbf{0 . 0 3}$ & 12.84 & 19.35 & 5.59 \\
\hline Saharanpur & 0.23 & 0.40 & 0.03 & 15.37 & 22.65 & 6.91 \\
\hline Muzaffarnagar & 0.34 & 0.64 & 0.01 & 16.09 & 23.75 & 7.19 \\
\hline Bijnor & 0.34 & 0.66 & 0.00 & 14.59 & 22.40 & 5.74 \\
\hline Moradabad & 0.21 & 0.38 & 0.00 & 11.87 & 18.29 & 4.47 \\
\hline Rampur & 0.10 & 0.18 & 0.01 & 8.94 & 13.90 & 3.23 \\
\hline Meerut & 0.73 & 1.35 & 0.02 & 21.83 & 29.66 & 12.69 \\
\hline Bulandshahr & 0.47 & 0.90 & 0.02 & 16.00 & 24.16 & 6.57 \\
\hline Aligarh & 0.44 & 0.80 & 0.03 & 15.02 & 22.63 & 6.18 \\
\hline Mathura & 0.36 & 0.66 & 0.01 & 14.31 & 22.32 & 4.91 \\
\hline Agra & 0.45 & 0.82 & 0.01 & 14.97 & 20.85 & 8.01 \\
\hline Mainpuri & 0.47 & 0.85 & 0.02 & 18.58 & 26.08 & 9.74 \\
\hline Etah & 0.33 & 0.60 & 0.02 & 13.09 & 19.46 & 5.55 \\
\hline Budaun & 0.14 & 0.24 & 0.02 & 7.82 & 12.50 & 2.28 \\
\hline Bareilly & 0.24 & 0.43 & 0.02 & 12.21 & 18.49 & 4.90 \\
\hline Pilibhit & 0.14 & 0.25 & 0.01 & 10.35 & 16.35 & 3.45 \\
\hline Shahjahanpur & 0.14 & 0.25 & 0.01 & 9.51 & 14.75 & 3.26 \\
\hline Kheri & 0.10 & 0.17 & 0.01 & 7.77 & 12.30 & 2.60 \\
\hline Sitapur & 0.13 & 0.25 & 0.00 & 8.56 & 13.50 & 2.83 \\
\hline Hardoi & 0.20 & 0.37 & 0.01 & 10.80 & 17.03 & 3.31 \\
\hline Unnao & 0.24 & 0.45 & 0.01 & 10.89 & 16.29 & 4.98 \\
\hline Lucknow & 0.34 & 0.60 & 0.04 & 16.09 & 21.97 & 9.50 \\
\hline Rae Bareli & 0.18 & 0.35 & 0.00 & 9.15 & 14.26 & 3.87 \\
\hline Farrukhabad & 0.59 & 1.05 & 0.01 & 13.84 & 19.97 & 6.56 \\
\hline Etawah & 0.53 & 0.98 & 0.02 & 21.22 & 29.14 & 11.77 \\
\hline Kanpur & 0.70 & 0.83 & 0.54 & 19.56 & 26.05 & 11.93 \\
\hline Jalaun & 0.47 & 0.90 & 0.00 & 20.56 & 30.39 & 8.72 \\
\hline Jhansi & 0.30 & 0.56 & 0.03 & 15.47 & 22.79 & 7.16 \\
\hline Hamirpur & 0.15 & 0.28 & 0.00 & 12.42 & 19.51 & 4.09 \\
\hline Banda & 0.10 & 0.19 & 0.00 & 8.96 & 14.45 & 2.65 \\
\hline Fatehpur & 0.14 & 0.28 & 0.00 & 11.14 & 17.44 & 4.14 \\
\hline Pratabgarh & 0.22 & 0.46 & 0.01 & 11.45 & 18.47 & 4.67 \\
\hline Allahabad & 0.30 & 0.59 & 0.01 & 11.23 & 17.57 & 4.21 \\
\hline Barabanki & 0.06 & 0.12 & 0.00 & 8.40 & 13.41 & 2.76 \\
\hline Faizabad & 0.17 & 0.35 & 0.00 & 12.14 & 18.45 & 5.67 \\
\hline Sultanpur & 0.08 & 0.17 & 0.00 & 9.30 & 14.98 & 3.45 \\
\hline Bahraich & 0.07 & 0.13 & 0.00 & 5.62 & 9.26 & 1.34 \\
\hline Gonda & 0.13 & 0.24 & 0.02 & 5.89 & 9.73 & 1.57 \\
\hline Basti & 0.10 & 0.21 & 0.00 & 9.81 & 15.95 & 3.33 \\
\hline Gorakhpur & 0.35 & 0.69 & 0.03 & 12.74 & 20.34 & 4.85 \\
\hline Deoria & 0.34 & 0.70 & 0.00 & 12.70 & 20.19 & 5.09 \\
\hline Azamgarh & 0.24 & 0.48 & 0.03 & 13.93 & 20.88 & 7.15 \\
\hline Ballia & 0.60 & 1.22 & 0.01 & 17.99 & 27.25 & 8.20 \\
\hline Jaunpur & 0.22 & 0.46 & 0.00 & 12.33 & 19.71 & 5.03 \\
\hline Ghazipur & 0.31 & 0.63 & 0.00 & 16.20 & 24.99 & 7.12 \\
\hline Varanasi & 0.38 & 0.74 & 0.02 & 14.11 & 21.49 & 5.97 \\
\hline Mirzapur & 0.12 & 0.24 & 0.00 & 7.26 & 11.70 & 2.40 \\
\hline
\end{tabular}

Source: Census of India, Uttar Pradesh, Social and Cultural Tables, 1961 and 2001 


\section{Caste-Wise Percentage of Literates among Scheduled Caste:}

Though educational achievement among scheduled caste is significantly low, but within the scheduled caste there is a wide disparity between the castes in terms of literacy. Out of 66 caste groups in the state, 8 major castes constitute more than $90 \%$ of the scheduled caste population, while remaining 58 castes constitute $10 \%$ of scheduled population of the state.

Some castes made significant progress in educational attainment while others have still lagged behind. Their educational backwardness is the result of their long association with their traditional occupation. Caste wise analysis of literacy shows that Shilpkar is the most literate caste; percentage of literates among them was 11.57 percent in 1961 which rose to 35.59 percent in 1991 . While throughout the period, the lowest literacy rate was recorded among Pasis. Chamars constitute more than 56 percent of the scheduled caste population of the state, but literacy among them was only 7.41 percent in 1961 and 22.17 percent in 1991 . Within these caste females are most deprived. Within the span of 30 years literacy among different castes has increased but females are still backward in terms of literacy. In 1991, 4.68 percent of Pasi female was literate while male literacy among them was 25.14 percent. Social prejudices and economic deprivation is the cause of low literacy among different castes group and specially women within the castes. Table 6 shows the literacy rates among different castes.

Table 6: Caste-Wise Shares of Literates in Uttar Pradesh, 1961-1991

\begin{tabular}{|l|c|r|r|r|r|r|}
\hline Castes & \multicolumn{3}{|c|}{$\mathbf{1 9 6 1}$} & \multicolumn{3}{c|}{$\mathbf{1 9 9 1}$} \\
\hline All Caste & Total & Male & Female & Total & \multicolumn{1}{c|}{ Male } & Female \\
\hline Major Caste & $\mathbf{7 . 1 4}$ & $\mathbf{1 2 . 7 9}$ & $\mathbf{1 . 1 4}$ & $\mathbf{2 1 . 0 8}$ & $\mathbf{3 2 . 2 7}$ & $\mathbf{8 . 3 1}$ \\
\hline Chamar & \multicolumn{3}{|l|}{} & & & \\
\hline Pasi & 7.41 & 13.47 & 0.94 & 22.17 & 34.18 & 8.38 \\
\hline Dhobi & 5.25 & 9.46 & 0.83 & 15.47 & 25.14 & 4.68 \\
\hline Kori & 7.20 & 12.65 & 1.41 & 22.49 & 34.17 & 9.05 \\
\hline Balmiki & 6.50 & 11.41 & 1.52 & 21.69 & 32.62 & 9.01 \\
\hline Shilpkar & 8.06 & 13.09 & 2.46 & 22.73 & 31.99 & 12.06 \\
\hline Dhanuk & 11.57 & 20.99 & 1.66 & 35.59 & 49.64 & 21.18 \\
\hline Khatik & 8.21 & 13.66 & 2.10 & 22.21 & 31.72 & 10.98 \\
\hline Other Minor Caste & 9.51 & 15.66 & 2.73 & 22.07 & 32.38 & 10.23 \\
\hline Unclassfied & 6.11 & 10.71 & 1.25 & 16.78 & 25.52 & 6.90 \\
\hline
\end{tabular}

Source: Census of India, Uttar Pradesh: Special Tables for Scheduled Castes, 1961 and 1991

\section{Education among different Castes of Scheduled Castes:}

Scheduled castes are most backward in terms of educational achievement, but within them there are great disparities in the state. In order to assess the educational attainment of the different caste groups, 8 major castes have been selected out of the 66 castes in the state on the basis of their share in the total scheduled caste population and have been categorized as "major castes", while the remaining 58 castes which constitutes about 6 percent of the scheduled caste population of the state are nominated as "minor castes". Table 7 indicates that out of the 8 major caste groups in the state, Shilpkar caste has the highest share in total scheduled caste population which has attained primary level of education between 1961 and 1991 (2.54 and 11.67 respectively). A lower level of educational attainment was recorded among the Pasi caste and only 1.30 percent of the total Pasis in 1961 and 4.36 percent in 1991, attained education at the primary level. The share of females in this respect was negligibly low. Matriculation and higher level of education among them was attained by only 0.16 percent in 1961 and 5.67 percent in 1991. The Chamar caste which constitutes 56 percent of the total scheduled caste population had only 1.66 percent of their total population in this category in 1961 and 5.86 percent in 1991 . Their low level of educational attainment is the result of their long association with their traditional occupation, in which education has little role to play. 
Table 7: Level of Education among Different Castes of Scheduled Caste Population In Uttar Pradesh, 1961-1991

\begin{tabular}{|c|c|c|c|c|c|c|}
\hline \multirow[b]{3}{*}{ Castes } & \multicolumn{6}{|c|}{1961} \\
\hline & \multicolumn{3}{|c|}{$\begin{array}{c}\text { Primary Level } \\
\text { (percentages to the total SC } \\
\text { population) }\end{array}$} & \multicolumn{3}{|c|}{$\begin{array}{l}\text { Matriculation \& above Level } \\
\text { (percentages to the total SC } \\
\text { population) }\end{array}$} \\
\hline & Total & Male & Female & Total & Male & Female \\
\hline All Caste & 1.58 & 2.89 & 0.19 & 0.29 & 0.53 & 0.03 \\
\hline \multicolumn{7}{|l|}{ Major Castes } \\
\hline Chamar & 1.66 & 3.06 & 0.17 & 0.33 & 0.63 & 0.02 \\
\hline Pasi & 1.30 & 2.45 & 0.10 & 0.16 & 0.30 & 0.02 \\
\hline Dhobi & 1.73 & 3.12 & 0.26 & 0.32 & 0.59 & 0.04 \\
\hline Kori & 1.48 & 2.68 & 0.27 & 0.27 & 0.40 & 0.14 \\
\hline Balmiki & 1.43 & 2.41 & 0.33 & 0.18 & 0.31 & 0.03 \\
\hline Shilpkar & 2.54 & 4.50 & 0.49 & 0.29 & 0.50 & 0.06 \\
\hline Dhanuk & 1.77 & 3.01 & 0.38 & 0.26 & 0.45 & 0.04 \\
\hline Khatik & 1.89 & 3.32 & 0.32 & 0.36 & 0.66 & 0.03 \\
\hline Other Minor Castes & 1.08 & 1.94 & 0.17 & 0.18 & 0.32 & 0.03 \\
\hline \multirow{2}{*}{ Unclassfied } & 1.49 & 2.63 & 0.29 & 0.47 & 0.85 & 0.08 \\
\hline & \multicolumn{6}{|c|}{1991} \\
\hline All Caste & 5.81 & 8.65 & 2.56 & 8.56 & 14.09 & 2.25 \\
\hline \multicolumn{7}{|l|}{ Major Castes } \\
\hline Chamar & 5.86 & 8.77 & 2.51 & 9.41 & 15.55 & 2.35 \\
\hline Pasi & 4.36 & 7.03 & 1.38 & 5.67 & 9.80 & 1.05 \\
\hline Dhobi & 6.26 & 9.16 & 2.91 & 9.30 & 15.29 & 2.41 \\
\hline Kori & 6.52 & 9.57 & 2.99 & 8.65 & 13.89 & 2.57 \\
\hline Balmiki & 7.27 & 10.10 & 4.01 & 8.10 & 12.47 & 3.06 \\
\hline Shilpkar & 11.67 & 16.07 & 7.17 & 11.03 & 17.52 & 4.36 \\
\hline Dhanuk & 6.45 & 8.85 & 3.62 & 9.11 & 14.13 & 3.18 \\
\hline Khatik & 6.05 & 8.50 & 3.23 & 9.23 & 14.57 & 3.09 \\
\hline Other Minor Castes & 4.76 & 7.09 & 2.13 & 6.45 & 10.42 & 1.96 \\
\hline Unclassfied & 6.34 & 8.32 & 4.00 & 10.94 & 16.02 & 4.90 \\
\hline
\end{tabular}

Source: Census of India, Uttar Pradesh: Special Tables for Scheduled Castes, 1961 and 1991

\section{Disparities in Literacy:}

The characteristic feature of the any pluralistic society like India is the co-existence of various social, ethnic and racial groups. The inequality in literacy and educational attainment to a considerable extent attributed to these factors. Disparity refers to unequal distribution of some of the traits between two groups of same population or between different strata of population. The unequal distribution of literacy rates can be attributed to the factors like historical legacies and differences in socio-demographic and economic development. The inequality in educational attainment is not purely an educational issue; rather it cuts across the entire social, economic and political fabric of a nation. The social disparities that show up in educational systems are the reflection of deeply embedded inequalities in the whole society and economy ${ }^{6}$.

\section{Male-Female Disparity in Literacy among Scheduled Caste Population:}

In 1961, sex disparity among scheduled caste was very high in nearly all the districts of the state. Table 8 demonstrates that during this period sex disparity in the state was 1.08 . For rural areas disparity index was 1.25 while for urban areas it was 0.62 . District-wise analysis shows that the highest sex disparity index among scheduled caste was observed in the district of Basti (1.66) while the lowest was found in Rae Bareilly $(0.53)$. The districts which show sex disparity less than state average were Kanpur, Bareilly, Lucknow, Etawah, Mainpuri, Etah, Bijnor, Farrukhabad, Agra and Allahabad. In these districts sex disparity among total population was also low and level of literacy was high. All other districts show sex disparity index greater than the state average for scheduled castes.

\footnotetext{
${ }^{6}$ Moonis Raza and K.K. Premi (1987), "Indicators of Equity in Education: A Conceptual Frame Work", Journal of Educational Planning and Administration, Vol. 1, No. 2, pp. 1-29.
} 
Table 8: District-Wise Sex Disparity in Literacy among Scheduled Caste Population, 1961- 2001

\begin{tabular}{|c|c|c|c|c|c|c|}
\hline \multirow[b]{2}{*}{ Districts } & \multicolumn{3}{|c|}{1961} & \multicolumn{3}{|c|}{2001} \\
\hline & Total & Rural & Urban & Total & Rural & Urban \\
\hline Uttar Pradesh & 1.08 & 1.25 & 0.62 & 0.36 & 0.39 & 0.24 \\
\hline Saharanpur & 1.17 & 1.40 & 0.40 & 0.30 & 0.31 & 0.19 \\
\hline Muzaffarnagar & 1.11 & 1.51 & 0.33 & 0.34 & 0.35 & 0.26 \\
\hline Bijnor & 0.98 & 1.04 & 0.57 & 0.34 & 0.35 & 0.27 \\
\hline Moradabad & 1.15 & 1.44 & 0.69 & 0.40 & 0.44 & 0.25 \\
\hline Rampur & 1.27 & 1.32 & 1.09 & 0.39 & 0.41 & 0.25 \\
\hline Meerut & 1.22 & 1.57 & 0.70 & 0.29 & 0.33 & 0.23 \\
\hline Bulandshahr & 1.37 & 1.41 & 1.16 & 0.39 & 0.42 & 0.29 \\
\hline Aligarh & 1.05 & 1.32 & 0.63 & 0.37 & 0.40 & 0.27 \\
\hline Mathura & 1.27 & 1.49 & 0.80 & 0.40 & 0.44 & 0.28 \\
\hline Agra & 0.99 & 1.23 & 0.71 & 0.31 & 0.40 & 0.22 \\
\hline Mainpuri & 0.92 & 0.98 & 0.57 & 0.28 & 0.30 & 0.22 \\
\hline Etah & 0.98 & 1.00 & 0.79 & 0.36 & 0.38 & 0.26 \\
\hline Budaun & 1.21 & 1.32 & 0.76 & 0.38 & 0.39 & 0.30 \\
\hline Bareilly & 0.80 & 1.25 & 0.46 & 0.32 & 0.36 & 0.22 \\
\hline Pilibhit & 1.11 & 1.26 & 0.68 & 0.36 & 0.37 & 0.25 \\
\hline Shahjahanpur & 1.22 & 1.19 & 1.83 & 0.32 & 0.33 & 0.22 \\
\hline Kheri & 1.13 & 1.23 & 0.43 & 0.37 & 0.38 & 0.25 \\
\hline Sitapur & 1.40 & 1.44 & 0.91 & 0.38 & 0.39 & 0.25 \\
\hline Hardoi & 1.20 & 1.22 & 0.88 & 0.40 & 0.41 & 0.26 \\
\hline Unnao & 1.15 & 1.15 & 0.90 & 0.34 & 0.35 & 0.22 \\
\hline Lucknow & 0.82 & 1.44 & 0.47 & 0.27 & 0.34 & 0.18 \\
\hline Rae Bareli & 0.53 & 0.52 & 1.07 & 0.39 & 0.40 & 0.28 \\
\hline Farrukhabad & 0.96 & 1.00 & 0.71 & 0.29 & 0.31 & 0.21 \\
\hline Etawah & 0.85 & 0.86 & 0.75 & 0.26 & 0.26 & 0.20 \\
\hline Kanpur & 0.61 & 1.11 & 0.36 & 0.23 & 0.26 & 0.17 \\
\hline Jalaun & 1.27 & 1.32 & 1.11 & 0.36 & 0.38 & 0.27 \\
\hline Jhansi & 1.01 & 1.53 & 0.74 & 0.37 & 0.43 & 0.25 \\
\hline Hamirpur & 1.26 & 1.29 & 1.11 & 0.42 & 0.44 & 0.35 \\
\hline Banda & 1.36 & 1.38 & 1.22 & 0.35 & 0.36 & 0.31 \\
\hline Fatehpur & 1.24 & 1.25 & 1.12 & 0.37 & 0.38 & 0.30 \\
\hline Pratapgarh & 1.38 & 1.38 & 1.36 & 0.40 & 0.40 & 0.31 \\
\hline Allahabad & 0.99 & 1.31 & 0.70 & 0.42 & 0.46 & 0.23 \\
\hline Barabanki & 1.67 & 1.69 & 1.30 & 0.39 & 0.40 & 0.31 \\
\hline Faizabad & 1.44 & 1.43 & 1.67 & 0.36 & 0.36 & 0.26 \\
\hline Sultanpur & 1.52 & 1.54 & 1.16 & 0.40 & 0.40 & 0.29 \\
\hline Bahraich & 1.76 & 1.82 & 1.11 & 0.52 & 0.53 & 0.26 \\
\hline Gonda & 1.07 & 1.66 & 0.32 & 0.53 & 0.55 & 0.30 \\
\hline Basti & 1.66 & 1.75 & 1.03 & 0.45 & 0.45 & 0.35 \\
\hline Gorakhpur & 1.28 & 1.60 & 0.57 & 0.43 & 0.45 & 0.29 \\
\hline Deoria & 1.55 & 1.60 & 0.85 & 0.44 & 0.44 & 0.32 \\
\hline Azamgarh & 1.23 & 1.34 & 0.34 & 0.34 & 0.34 & 0.29 \\
\hline Ballia & 1.54 & 1.54 & 1.48 & 0.39 & 0.39 & 0.37 \\
\hline Jaunpur & 1.56 & 1.63 & 0.87 & 0.38 & 0.39 & 0.34 \\
\hline Ghazipur & 1.31 & 1.38 & 0.81 & 0.39 & 0.39 & 0.31 \\
\hline Varanasi & 1.10 & 1.20 & 0.85 & 0.41 & 0.43 & 0.29 \\
\hline Mirzapur & 1.45 & 1.48 & 1.29 & 0.47 & 0.50 & 0.30 \\
\hline
\end{tabular}

Source: Census of India, Uttar Pradesh, Social and Cultural Tables, 1961 and 2001

In rural areas the highest sex disparity among scheduled caste was found in Basti (1.75) and the lowest in Rae Bareilly (0.52) followed by the districts of Etawah (0.86) and Mainpuri (0.98). All other districts show sex disparity index greater than state average for rural areas. On the other hand in urban areas the highest sex disparities among scheduled castes observed in the district of Faizabad while the lowest disparity index found in Gonda, Muzaffarnagar, Azamgarh, Kanpur and Saharanpur in the range of 0.32 to 0.40 . 
In 2001, sex disparities among the scheduled caste have reduced significantly. The disparity index among the scheduled caste of Uttar Pradesh was 0.36, while in rural and urban areas it was 0.39 and 0.24 respectively. District-wise analysis of the data shows that in all the districts sex disparity among scheduled caste has reduced over the study period. The highest sex disparity among scheduled caste in 2001 was recorded in the district of Gonda (0.53) followed by Bahraich, Basti, Gorakhpur and Deoria. In all these districts sex disparity among total population was also high. The lowest disparity was found in Kanpur 0.23. More or less the same pattern was observed in rural and urban areas. The sex disparity among scheduled caste was high in the rural areas as compared to the urban areas.

\section{Disparity in Literacy between Non-Scheduled and Scheduled Caste Population}

Inequality or disparities exists not only between genders and rural-urban populations but also between non-scheduled caste and scheduled caste population. The non-scheduled population is in a better position than scheduled caste population, like wise rural and urban non scheduled populations are advanced educationally than their scheduled caste counterpart.

Table 9 shows the disparity in literacy between the scheduled caste and non-scheduled caste population. In 1961, the index of disparity between them was 0.49 in Uttar Pradesh. In rural areas such disparity was of the magnitude of 0.45 and in urban areas it was 0.41. A quick glance at the non-scheduled caste and scheduled caste disparity index reveals that the highest disparity between these two groups of population existed in the districts of Sultanpur (0.79) while the lowest disparity was found in Mainpuri $(0.27)$. The districts which have non scheduled caste and scheduled caste disparities less than state average are Etah, Etawah, Meerut, Bulandshahr, Bijnor, Jalaun, Kanpur, Aligarh, Muzaffarnagar, Unnao, Jhansi, Pilibhit, Mathura and Agra. All other districts show disparity between non-scheduled caste and scheduled caste greater than the state average. In rural areas the magnitude of disparity between these two groups of population was the highest again in the district of Sultanpur (0.78), while it was the lowest in Mainpuri and Etah districts (0.24). In the urban areas the disparities in literacy between non-scheduled caste and scheduled caste population was the highest in Barabanki (0.78) while the lowest was in the district of Gonda (0.04). One of the interesting feature which the data shows is that in urban areas disparities between these two groups of population are highest in majority of the districts of the state while in the case of rural areas these districts shows low disparity between non-scheduled caste and scheduled caste groups of population.

In 2001, the disparity in literacy between non-scheduled caste and scheduled caste was declined. It was 0.15 for the state average, while in rural areas it was 0.12 and in urban areas 0.14 . The analysis of the disparity index of 46 districts of the state reveals that all the eastern districts of the state shows very high non-scheduled caste and scheduled caste disparity while the western districts which is educationally advanced shows very low disparity in literacy between two groups of the population. In rural areas in 2001, scheduled caste populations of Rampur, Budaun and Bareilly districts have literacy higher than their non-scheduled caste population. So in these districts there was no disparity in literacy against scheduled caste population. In urban areas the lowest disparity in literacy between non-scheduled caste and scheduled caste population was found in Saharanpur, Rampur and Bareilly (0.02), while the highest was recorded in the district of Barabanki. Thus the data demonstrate that in 2001 also disparity in literacy between two groups of population was high in urban areas. This trend was visible in almost all the districts of the state.

Table 9: Disparity in Literacy between Scheduled and Non-Scheduled Caste Population, 1961- 2001

\begin{tabular}{|l|c|c|c|c|c|c|}
\hline \multirow{2}{*}{ Districts } & \multicolumn{3}{|c|}{$\mathbf{1 9 6 1}$} & \multicolumn{3}{c|}{$\mathbf{2 0 0 1}$} \\
\cline { 2 - 7 } & Total & Rural & Urban & Total & Rural & Urban \\
\hline Uttar Pradesh & $\mathbf{0 . 4 9}$ & $\mathbf{0 . 4 5}$ & $\mathbf{0 . 4 1}$ & $\mathbf{0 . 1 5}$ & $\mathbf{0 . 1 2}$ & $\mathbf{0 . 1 4}$ \\
\hline Saharanpur & 0.57 & 0.40 & 0.72 & 0.05 & 0.02 & 0.02 \\
\hline Muzaffarnagar & 0.44 & 0.39 & 0.49 & 0.06 & 0.05 & 0.05 \\
\hline Bijnor & 0.37 & 0.32 & 0.37 & 0.07 & 0.06 & 0.09 \\
\hline Moradabad & 0.49 & 0.36 & 0.43 & 0.05 & 0.01 & 0.07 \\
\hline Rampur & 0.64 & 0.53 & 0.37 & 0.03 & -0.03 & 0.02 \\
\hline Meerut & 0.34 & 0.26 & 0.41 & 0.07 & 0.05 & 0.08 \\
\hline Bulandshahr & 0.36 & 0.33 & 0.39 & 0.11 & 0.09 & 0.12 \\
\hline Aligarh & 0.43 & 0.40 & 0.42 & 0.12 & 0.11 & 0.16 \\
\hline Mathura & 0.48 & 0.42 & 0.46 & 0.12 & 0.08 & 0.18 \\
\hline Agra & 0.48 & 0.35 & 0.59 & 0.15 & 0.10 & 0.20 \\
\hline Mainpuri & 0.27 & 0.24 & 0.40 & 0.08 & 0.08 & 0.10 \\
\hline Etah & 0.28 & 0.24 & 0.49 & 0.12 & 0.10 & 0.17 \\
\hline Budaun & 0.59 & 0.53 & 0.56 & 0.04 & -0.01 & 0.17 \\
\hline Bareilly & 0.54 & 0.45 & 0.35 & 0.03 & -0.02 & 0.02 \\
\hline
\end{tabular}




\begin{tabular}{|c|c|c|c|c|c|c|}
\hline Pilibhit & 0.47 & 0.40 & 0.47 & 0.07 & 0.05 & 0.05 \\
\hline Shahjahanpur & 0.57 & 0.49 & 0.61 & 0.10 & 0.08 & 0.09 \\
\hline Kheri & 0.54 & 0.50 & 0.43 & 0.14 & 0.11 & 0.22 \\
\hline Sitapur & 0.55 & 0.49 & 0.53 & 0.16 & 0.13 & 0.17 \\
\hline Hardoi & 0.50 & 0.47 & 0.34 & 0.15 & 0.13 & 0.16 \\
\hline Unnao & 0.44 & 0.42 & 0.59 & 0.18 & 0.16 & 0.15 \\
\hline Lucknow & 0.73 & 0.58 & 0.46 & 0.25 & 0.17 & 0.16 \\
\hline Rae Bareli & 0.51 & 0.49 & 0.50 & 0.25 & 0.23 & 0.23 \\
\hline Farrukhabad & 0.33 & 0.29 & 0.50 & 0.16 & 0.15 & 0.17 \\
\hline Etawah & 0.34 & 0.31 & 0.36 & 0.12 & 0.10 & 0.13 \\
\hline Kanpur & 0.42 & 0.47 & 0.30 & 0.18 & 0.15 & 0.16 \\
\hline Jalaun & 0.36 & 0.36 & 0.31 & 0.10 & 0.09 & 0.09 \\
\hline Jhansi & 0.46 & 0.46 & 0.34 & 0.13 & 0.11 & 0.11 \\
\hline Hamirpur & 0.57 & 0.58 & 0.50 & 0.14 & 0.12 & 0.16 \\
\hline Banda & 0.72 & 0.70 & 0.71 & 0.15 & 0.12 & 0.23 \\
\hline Fatehpur & 0.64 & 0.63 & 0.60 & 0.19 & 0.18 & 0.24 \\
\hline Pratapgarh & 0.54 & 0.52 & 0.53 & 0.20 & 0.19 & 0.20 \\
\hline Allahabad & 0.64 & 0.65 & 0.47 & 0.27 & 0.25 & 0.21 \\
\hline Barabanki & 0.68 & 0.64 & 0.78 & 0.20 & 0.19 & 0.30 \\
\hline Faizabad & 0.47 & 0.42 & 0.58 & 0.19 & 0.17 & 0.21 \\
\hline Sultanpur & 0.79 & 0.78 & 0.59 & 0.23 & 0.22 & 0.28 \\
\hline Bahraich & 0.58 & 0.54 & 0.61 & 0.15 & 0.12 & 0.16 \\
\hline Gonda & 0.57 & 0.60 & 0.04 & 0.21 & 0.18 & 0.20 \\
\hline Basti & 0.62 & 0.61 & 0.63 & 0.14 & 0.13 & 0.27 \\
\hline Gorakhpur & 0.53 & 0.50 & 0.31 & 0.14 & 0.11 & 0.21 \\
\hline Deoria & 0.50 & 0.49 & 0.58 & 0.15 & 0.13 & 0.25 \\
\hline Azamgarh & 0.50 & 0.49 & 0.29 & 0.15 & 0.13 & 0.21 \\
\hline Ballia & 0.49 & 0.47 & 0.69 & 0.13 & 0.11 & 0.25 \\
\hline Jaunpur & 0.53 & 0.51 & 0.53 & 0.16 & 0.15 & 0.26 \\
\hline Ghazipur & 0.50 & 0.50 & 0.36 & 0.14 & 0.13 & 0.18 \\
\hline Varanasi & 0.56 & 0.49 & 0.55 & 0.20 & 0.19 & 0.16 \\
\hline Mirzapur & 0.72 & 0.70 & 0.50 & 0.33 & 0.30 & 0.22 \\
\hline
\end{tabular}

Source: Census of India, Uttar Pradesh, Social and Cultural Tables, 1961and 2001

The analysis of male female literacy and literacy between social groups' shows that the sex disparity was the highest in 1961 and although it was narrowed down in 2001 but still the gap is very wide. In Uttar Pradesh the male female disparities in literacy are the highest in the eastern states. These districts are also most backward in literacy. The western districts are most advanced as far as the literacy is concerned. It clearly shows that lower literacy contributes for higher sex disparities while its reverse is not necessarily true.

\section{Conclusions:}

The analysis of data clearly indicates that in 1961, percentage of literate among the Scheduled Castes in Uttar Pradesh was far behind the rest of the population. Only 6.97 percent of the scheduled castes were literate while literacy in the total population was 17.34 percent. In 2001 also the literacy in the scheduled caste population in the state was 36.75 percent while literacy in the total population was 45.56 percent. This shows the relative backwardness of the scheduled caste population through out the period. Strict caste prejudices and poor socio- economic conditions are the causes of the relative backwardness of this segment of the state's population.

We find that the percentage of literates within scheduled caste population is particularly small in the districts in which their population is high. Another interesting feature is that all those districts where literacy among general population is high, scheduled caste literacy rates are also high. Over all educational attainment among scheduled castes both at the primary and matriculation and above levels has increased over the period under study, but when we compare these levels with those of the total population, we find that this group is still most backward educationally. The condition of scheduled caste females is most depressing.

Caste-wise analysis of the data shows that the Chamar caste which constitutes 56 percent of the total scheduled caste population of the state has only 7.41 percent literacy in 1961 and 22.17 percent in 1991, i.e., more than half of the scheduled caste population has very low level of literacy. The caste system was responsible to some extent for the backwardness of education among them. Nearly one quarter of the total number of Hindus were considered so impure that a member of a higher caste after contact with them was 
required to bathe. Though the schools were open to all, the admission of a boy belonging to one of these impure castes was not encouraged.

The scheduled caste population had been kept out of formal education for centuries due to social norms. The data shows that sex disparity among scheduled caste population was very high in almost all the districts of the state in 1961. While, in 2001 sex disparity among them reduced significantly in the case of total, rural and urban population. It is also evident that educationally advanced districts exhibit a lower sex disparity in literacy among the scheduled caste population.

The analysis of disparity in literacy among social groups like scheduled castes and non-scheduled castes shows that in 1961, in the urban areas disparities in literacy between non-scheduled caste and scheduled caste was high in the majority of the districts as compared to the rural areas. This trend was also visible in 2001. It can hence be inferred that urbanization has little impact on reducing educational disparities.

Thus we can conclude that despite the fact that significant strides in the field of education have been made since Independence, only 36.75 percent of the scheduled castes population in the state can read and write. Interestingly literacy has made a significant progress only in those districts of the state that were prominent on the literacy map of the state at the beginning of the Twentieth century. The efforts in raising the educational status of the scheduled castes have had certain positive results, but they have not yet attacked the issue of inequality of educational opportunities in any significant way. As a result it has been seen that this community continue to remain educationally disadvantaged in comparison to the general population. Regionally, relatively high literacy rates were the characteristic of the areas where educational reforms have had an early start. There is also need to adopt special schemes to develop the regions which have been educationally backward since the colonial period and require special remedial measures to raise their levels of literacy and educational attainment.

\section{References:}

[1] Aggarwal, S.P. and J.C. Aggarwal (1997), "Development of Education in India - Select Documents 1993 - 94 ”, Concept Publishing Company, New Delhi.

[2] Aggarwal, Y.P. and Vemuri, M (1986), "Temporal Analysis of Disparities in the Levels of Literacy between Scheduled Caste and Non-Scheduled Caste Population in Tilak J.B.J (ed), Education and Regional Development, Yatan Publications, New Delhi.

[3] Aggarwal, Yash (1987), "Some Aspects of Educational Development among Scheduled Caste Population in India", Journal of Educational Planning and Administration, Vol. 1, No. 2, pp. 137-164.

[4] Aggarwal, Yash (1998), "Some Aspects of Social and Economic Inequities among SCs in India", Journal of Higher Education, Vol. 21, No. 3, pp. 415-432.

[5] Aikara, Jacob (1996), "Inequalities of Educational Opportunities: The Case of Scheduled Castes in India", Journal of Educational Planning and Administration, Vol. X, No. 1, January, pp. 1-14.

[6] Barak, V.K. and Binay M. Lakra (2003), "Literacy of the Scheduled Tribes in Jharkhand: Patterns and Disparities, 1991-2001", Indian Journal of Adult Education, Vol. 64, No. 3-4, pp. 19-34.

[7] Buragohain, Tarujyoti (1997), "Differentials in Literacy Rate by Social Groups: An Analysis of Census Data across States", Margin, April-June \& Jul-Sept. Vol. 29, No. 3\&4, pp. 267-282.

[8] Chatterjee, S.K. (2000), "Educational Development of Scheduled Castes: Looking Ahead", Gyan Publishing House, New Delhi.

[9] Datt, Ruddar (1996), "Inequalities in Educational Development with Special Reference to Literacy Status and School Education", Journal of Educational Planning and Administration, Vol. X, No.3, July, pp. 255-269.

[10] Ghosh, P.K. (1998), "Disparity and Some Possible Determinants of Rural Literacy/Education”, IASSI Quarterly, Vol. 17, No. 1, July -Sept, pp. 124-142.

[11] Ghosh, S.C. (2000), "The History of Education in Modern India", Orient Longman.

[12] Goel, S.C. (1974), "Education and Economic Growth in India", Comparative Education, Vol. 10, No. 2, pp. 147-158.

[13] Joshi, Hemlata (2000), "Changing Literacy Level in Rajasthan: A Geographical Analysis", Geographical Review of India, Vol. 62 , No.2, pp. $150-160$.

[14] Krishnan, S. Raju (2002), "Literacy in India: Current Scenario and Changes during the Last Decades", Demography India, Vol. 31, No. 1, pp. 51-64.

[15] Mishra, N. (2001), "Scheduled Caste Education: Issues and Aspects", Kalpaz Publications, New Delhi.

[16] Mukherji, S.N. (1964), "Education in India: Today and Tomorrow", Acharya Book Depot, Vadodra.

[17] (1974), "History of Education in India-Modern Period", Acharya Book Depot, Baroda.

[18] Nurullah, S and J.P. Naik (1943), "A Students' History of Education in India”, Macmillan, Bombay.

[19] Pandey, Balaji (1986): “Educational Development among Scheduled Castes", Social Scientist, Vol. 14, No. 2-3, Feb-Mar., pp. 5968.

[20] Paranjape, Madhu S. (2007), "Uneven Distribution of Education in Maharashtra: Rural -Urban, Gender and Caste Inequalities", Economic and Political Weekly, Vol. 42, No. 3, March 5; pp. 213-16.

[21] Rao, Hemlata (1993), "Inter-District Disparities in Educational Development in Karnataka", in Nuna Sheel C. (ed), Regional Disparities in Educational Development, South Asian Publishers Pvt. Ltd., New Delhi.

[22] Reddy, B. Shiva \& P. Sanjeeva Reddy (1992), "Inequality of Educational Opportunity in Rural Areas: A Case Study", Journal of Educational Planning and Administration, Vol. VI, No. 3, July, pp. 237-250.

[23] Sachidananda and R.P Sinha (1989), "Education and the Disadvantaged", Uppal Publishing House, New Delhi.

[24] Sagar, Prem (1991), "Regional Disparities in Literacy in India", Asian Profile, Vol. XIX, No.3, pp. 283-267.

[25] Singh, Puran (1989), "Problem of Education among Scheduled Castes", Mittal Publications, New Delhi.

[26] Zaidi, S.M.I.A. (1995), "Educational development in Himalayan Region of Uttar Pradesh", Journal of Educational Planning and Administration, Vol. IX, No. 3, July, pp. 273-287. 